Dr Miljko Erić, pukovnik, dipl. inž. dr Aleksandar Kostić, pukovnik, dipl. inž. Vojnotehnički institut, Beograd

\section{NADZOR VAZDUŠNOG PROSTORA PASIVNIM MULTISENZORSKIM SISTEMIMA}

UDC: $355.469 .7: 621.396 .663$

Rezime:

Za sprovođenje savremenih operacija, kako na operativno-strategijskom, tako i na taktičkom nivou, izuzetno je važno da se obezbedi kontinuirani nadzor vazdušnog prostora. Poznato je da su aktivni radarski sistemi, na kojima se kod nas trenutno zasniva nadzor vazdušnog prostora, u ratnim uslovima veoma ranjivi i podložni elektronskim i borbenim dejstvima protivnika, što je u toku rata 1999. godine i praktično potvrđeno. Kao alternativa aktivnim radarskim sistemima nameće se koncept pasivnog nadzora vazdušnog prostora korišćenjem distribuiranih multisenzorskih sistema. Predmet širih istraživanja predstavljaju tehnička rešenja integrisanog multisenzorskog sistema za pasivan nadzor vazdušnog prostora, koji se sastoji od sledećih podsistema za nadzor vazdušnog prostora: na radio-gonimetarskom principu u frekvencijskom opsegu 20-3000 MHz, na zvukometrijskom principu, na principu vizuelnih osmatračkih stanica, na termovizijskom i televizijskom principu. U ovom radu analizirani su opšti principi pasivnog nadzora vazdušnog prostora multisenzorskim sistemima $i$ predložena je tehnička koncepcija radio-goniometarskog i zvukometrijskog podsistema.

Ključne reči: nadzor vazdušnog prostora, radio izviđanje, radio-goniometrisanje, radio-tehničko izviđanje, zvukometrija, MUSIC metoda.

\title{
AIR SURVEILLANCE BY PASIVE MULTISENSOR SYSTEMS
}

\section{Summary:}

It is very important to provide continuous air surveillance in to realize modern operations on the operational-strategic level and tactical, as well. It is well known that active radar systems, on which air surveillance is based in our country, are very vulnerable in war times and susceptible to the electronic counter and combat attacks of the enemy, what is shown practically in 1999 war. Air surveillance by passive multi-sensor systems is a possible alternative to the air surveillance by the active radar systems. Subjects of our wider research are technical solutions of integrated multi-sensor systems for passive air surveillance which consists of the following subsystems: a subsystem for the air communication intelligence within the frequency range 20-3000 $\mathrm{MHz}$ based on intercept/direction finding principle, a subsystem for the air surveillance based on the acoustic intelligence, a subsystem for the air surveillance based on the station for the visual intelligence, a subsystem for air surveillance based on thermo-vision and television principle. General principles of air surveillance are presented, and the concepts of the subsystems for the air communication intelligence and acoustic intelligence are proposed in this paper.

Key words: air surveillance, communication inteligence, direction finding, acoustic inteligence, MUSIC method.

\section{Uvod}

Nadzor vazdušnog prostora (Air Surrveilance) važna je delatnost za svaku državu i ima pored civilnog i vojni - bez- bednosni značaj. Pod nadzorom vazdušnog prostora podrazumeva se obezbeđenje i upotreba informacija o objektima u vazdušnom prostoru radi sigurnog upravljanja vazdušnim saobraćajem civilnih i 
vojnih vazduhoplova i obezbeđenja suvereniteta vazdušnog prostora države. Obezbeđuje sigurno razdvajanje i brzo sekvenciranje vazdušnog saobraćaja, nadzor na prilazima i granicama kao i na teritoriji države radi sprečavanja neovlašćenog, namernog ili nenamernog narušavanja bezbednosti vlastitog vazdušnog prostora. Nadzor vazdušnog prostora obuhvata: detekciju, utvrđivanje pozicije određivanjem koordinata letelice u prostoru (visina leta ili nivo leta, geografska dužina i širina, odnosno x i y koordinate $\mathrm{u}$ zadatom koordinatnom sistemu), odredivanje identifikacione kategorije letelice i upravljanje vazdušnim saobraćajem.

$\mathrm{Za}$ realizaciju nadzora vazdušnog prostora većina država ima jedinstveni distribuirani sistem nadzora koji omogućava realizaciju navedenih procesa $\mathrm{i}$ funkcija. U miru, nadzor vazdušnog prostora vrši se primenom aktivnih radarskih sistema (primarnih i sekundarnih) i odgovarajućim računarskim sistemima za obradu, prikazivanje i telekomunikacionim sistemima za distribuciju podataka o situaciji u vazdušnom prostoru.

U ratu sistem za nadzor vazdušnog prostora postaje deo sistema za vođenje elektronskog rata. Radi preduzimanja pravovremenih odbrambenih i zaštitnih mera u ratu i kriznim situacijama, sistem za nadzor vazdušnog prostora treba da na strategijskom nivou obezbedi pravovremene informacije o narušavanju vazdušnog prostora od strane potencijalnog protivnika otkrivanjem - detekcijom, praćenjem, lociranjem i identifikacijom letelica protivnika izvan i iznad teritorije države. Na taktičkom nivou sistem treba da omogući neophodnu akviziciju za upravljanje vatrenim sistemima u protiv- vazdušnoj odbrani, kao i stvaranje elektronske slike bojišta (EOB - Electronic Order of Battle), na osnovu kojih se preduzimaju defanzivne mere zaštite ili ofanzivne elektronske ili borbene protivmere kao što je navođenje lovačke avijacije i upravljanje raketnim sistemima oružja u sistemu PVO.

Poznato je da su aktivni radarski sistemi, na kojima se kod nas zasniva sistem nadzora vazdušnog prostora, $u$ ratnim uslovima veoma ranjivi i podložni elektronskim i protivelektronskim borbenim dejstvima protivnika, što je u toku rata 1999. godine i potvrđeno. Kao alternativa aktivnim radarskim sistemima nameće se koncept nadzora vazdušnog prostora primenom distribuiranih pasivnih senzorskih sistema. Mogućnost nadzora vazdušnog prostora na pasivnom multisenzorskom principu proističe iz činjenice da vazduhoplovi emituju (ili reflektuju) energiju u elektromagnetskom, vidljivom i infracrvenom delu spektra, a takođe $u$ toku leta generišu akustičke signale na osnovu kojih se mogu detektovati. Daljina na kojoj se vazduhoplov može otkriti zavisi od udaljenosti, snage emitovanog zračenja, radarske refleksne površine, osetljivosti prijemnih senzora, uslova propagacije, uslova optičke vidljivosti, itd.

Osnovna prednost pasivnog principa nadzora vazdušnog prostora, u odnosu na aktivni princip koji se zasniva na korišćenju aktivnih radarskih sistema, je u tome što pasivni senzori ne predstavljaju izvore elektromagnetskog zračenja koje kompromituje njihovu poziciju i rad, čime se protivniku smanjuje mogućnost za preduzimanje efikasnih elektronskih i borbenih protivmera, što je izuzetno značajno u ratnim i kriznim situacijama. 
Pasivan princip nameće i određena ograničenja. Otkrivanje - detekcija, lociranje, praćenje i identifikacija vazduhoplova na pasivnom principu moguća je samo onda kada se vazduhoplov nađe na dovoljnoj udaljenosti sa koje se može detektovati elektromagnetska ili akustička energija koju vazduhoplov emituje u toku leta. Takođe, da bi se omogućilo lociranje odnosno praćenje trajektorije vazduhoplova, neophodno je da pasivni sistem bude distribuiran, što znači da su za određivanje lokacije na bilo kom pasivnom principu potrebni podaci sa više prostorno distribuiranih stanica, za razliku od aktivnih radarskih sistema gde se jednim radarom može odrediti smer i udaljenost (lokacija) vazduhoplova.

$U$ svetu su razvijeni i nalaze se $u$ operativnoj upotrebi sistemi za nadzor vazdušnog prostora na pasivnom multisenzorskom principu. Takođe, razvijen je „MULTI-SENSOR GRIDS“ koncept koji podrazumeva primenu svih vrsta aktivnih i pasivnih senzora radi obezbeđenja simultanog nadzora kompletnog vojišta u geografskom smislu, a ne samo vazdušnog prostora, što podrazumeva: nadzor pod morem, na moru, na kopnu, u vazdušnom prostoru i kosmosu. U posebnim multisenzorskim operativnim centrima vrši se fuzija podataka dobijenih iz različitih pasivnih sistema sa podacima dobijenim od radarskih sistema. Na ovaj način stvara se integralna slika vojišta u pogledu rasporeda snaga i sredstava, kao i u elektronskom smislu tj. u smislu zauzetosti i korišćenja elektromagnetskog spektra.

U miru bi se nadzor vazdušnog prostora i dalje dominantno zasnivao na primeni aktivnih radarskih sistema. U ratu nadzor vazdušnog prostora primarno bi se zasnivao na korišćenju pasivnih sistema, s tim što bi se aktivni sistemi uključivali samo povremeno i veoma kratko (par sekundi) i to radi potvrde slike stanja u vazdušnom prostoru koja je dobijena multisenzorskim pasivnim sistemima.

\section{Podsistem za pasivan nadzor vazdušnog prostora na radio-goniometarskom principu u frekvencijskom opsegu 20-3000 MHz}

Tehnička koncepcija podsistema za nadzor vazdušnog prostora na radio-goniometarskom principu zasniva se na ostvarenim rezultatima i tehničkim rešenjima koja su razrađena i verifikovana kroz prototipski razvoj radio-goniometara za VFF/UVF opseg 20-500 MHz koji je razvijen u VTI i usvojen u NVO pod nazivom RGK-2/3, kao i na iskustvima u primeni tog prototipa u toku rata 1999. godine.

\section{Vazduhoplovi kao izvori elektromagnetskog zračenja}

Vazduhoplovi, kao izuzetno složeni i skupi tehnički sistemi, kada su u vazdušnom prostoru, uvek su deo još složenijeg tehničkog sistema u okviru kojeg postoji potreba za razmenom komandi i informacija (komunikacija sa kontrolom leta, sa komandnim centrima na zemlji i u vazdušnom prostoru, između vazduhoplova, sa elementima na zemlji na operativnom $i$ taktičkom nivou itd.) pri čemu se, zbog mobilnosti vazduhoplova, ona ostvaruje korišćenjem tehnike radio-komunikacija. Pri tome, jasno je da je potreba za korišće- 
njem navedenih sredstava u korelaciji sa složenošću i cenom vazduhoplova. Komunikacijom se razmenjuju navigacioni, meteorološki i izviđački podaci, analogni i digitalizovani govor, video-signal. Tehnike prenosa koje se koriste su: AM modulacija (analogni govor), frekvencijsko skakanje, direktna sekvenca, hibridne tehnike (frekvencijsko skakanje + direktna sekvenca), FM, FSK. U pogledu raspodele korisničkih kanala koriste se FDMA, TDMA i CDMA koncepti. Pojedini frekvencijski opsezi su standardizovani za vazduhoplovne radio-komunikacije (npr. $110-157 \mathrm{MHz}, 225-400 \mathrm{MHz}$ ). Pored toga za vazduhoplovne komunikacije taktičke namene koristi se i opseg 30-88 MHz. $\mathrm{Za}$ veze sa udaljenim komandnim centrima koristi se i VF opseg od 2-30 MHz. Pri uskopojasnom single carrier prenosu tipične širine kanala su 3 i $25 \mathrm{kHz}$.

Uređaji za identifikaciju (IFF Identification Friend or Foe) predstavljaju poseban podsistem i na civilnim i na vojnim vazduhoplovima. On omogućava na aktivnom ili poluaktivnom principu identifikaciju vazduhoplova od strane kontrole leta, zemaljskih borbenih sistema na taktičkom nivou, vlastitih sistema za nadzor vazdušnog prostora, kao i vlastitih vazduhoplova. Za IFF sisteme standardizovane su i koriste se dve frekvencije i to 1030 i $1090 \mathrm{MHz}$.

Vazduhoplovi vojne borbene namene opremljeni su različitim aktivnim radarskim sistemima za akviziciju i praćenje ciljeva u vazdušnom prostoru, kao sistemima za aktivno vođenje raketa malog, srednjeg i velikog dometa, o čemu u ovom radu neće biti detaljnije reči.

Korišćenjem komunikacionih, navigacionih, radarskih uređaja, uređaja za identifikaciju i aktivno navođenje, vazduhoplovi posredno postaju izvor elektromagnetskog zračenja na osnovu kojeg se na pasivnom principu mogu otkriti $u$ vazdušnom prostoru.

\section{Koncept podsistema za pasivan nadzor vazdušnog prostora na radio-goniometarskom principu}

Podsistem za pasivan nadzor vazdušnog prostora na radio-goniometarskom principu treba da omogući otkrivanje detekciju vazduhoplova sa verovatnoćom bliskoj jedinici, njihovo lociranje i praćenje trajektorije u 3-D vazdušnom prostoru na bazi prijema $i$ analize radio-signala koji potiče od izvora elektromagnetskog zračenja na vazduhoplovu. Podsistem se sastoji od više prostorno dislociranih radio-goniometarskih stanica koje su uvezane komunikacionim linkovima u jedinstvenu radio-goniometarsku mrežu.

U oblasti teorije i prakse elektronskog rata uobičajeno je da se izviđanje izvora elektromagnetskog zračenja koje potiče od komunikacionih uređaja svrstava u COMINT - COMmunication INTeligence, dok se izviđanje svih drugih izvora elektromagnetskog zračenja (radari, sistemi za identifikaciju i drugi elektronski sistemi) svrstava u ELINT (ELectronic INTeligence) sisteme. U praksi se zasebno realizuju COMINT a zasebno ELINT sistemi, pri čemu se fuzija informacija koje se dobijaju od jednog i drugog sistema vrši na višoj hijerarhijskoj ravni u upravljačkim C4I stanicama.

U svetu se nalaze u upotrebi sistemi za pasivni nadzor vazdušnog prostora na principu izviđanja izvora elektromagnetskog zračenja koje se emituje sa vazdu- 
hoplova, koji pokrivaju frekvencijski opseg od $200 \mathrm{MHz}$ do $18 \mathrm{GHz}$ i obezbeđuju otkrivanje letelica na daljini do 500 km (npr. sistem VEGA i TAMARA). Ovi sistemi su tipa ELINT stanica i primarno su namenjeni za radio-tehničko izviđanje, odnosno za izviđanje radara koji se koriste na vazduhoplovu.

$\mathrm{U}$ frekvencijskom opsegu od 20 $\mathrm{MHz}$ do $3000 \mathrm{MHz}$, koji je od posebnog interesa sa aspekta nadzora vazdušnog prostora, preklapaju se frekvencijski opsezi rada COMINT i ELINT sistema, s obzirom da se ovaj frekvencijski opseg koristi za komunikacije, za radare i za IFF sisteme.

Frekvencijski opseg ELINT sistema tipično je od $500 \mathrm{MHz}$ do $18 \mathrm{GHz}$. Tehnička koncepcija ELINT sistema i stanica, tehnička rešenja antenskog i prijemnog sistema kao i algoritmi za obradu signala optimizovani su za efikasno presretanje i izviđanje radarskih signala. $\mathrm{S}$ druge strane, za frekvencijski opseg 20$3000 \mathrm{MHz}$ opciono (2-3000 MHz) u svetu se rade COMINT sistemi koji se sastoje od više širokopojasnih intercept/DF stanica uvezanih u mrežu, koje se po svojoj tehničkoj koncepciji približavaju tehničkoj koncepciji ELINT stanica jer su optimizovane za efikasno automatsko presretanje komunikacionih radio-signala. Ove stanice omogućavaju određivanje azimuta za prostorni sektor po elevaciji tipično $\pm 10^{\circ}$ najviše $\pm 25^{\circ}$. Ovo ograničenje proističe iz primenjenih metoda za goniometrisanje (najčešće se koristi interferometarska ili metoda korelacione interferometrije). Iz navedenih razloga ove stanice se ne mogu primeniti za otkrivanje vazduhoplova u čitavom 3-D prostornom sektoru koji je od interesa.
$\mathrm{Na}$ osnovu dosadašnjeg teorijskog i praktičnog iskustva, vlastitih rezultata istraživanja i razvoja radio-goniometra RGK-2/3, iskustava stečenih u njegovoj primeni za vreme rata 1999. godine kao i iskustva u operativnoj upotrebi postojećih sistema za nadzor vazdušnog prostora, došlo se do saznanja da je u frekvencijskom opsegu $20 \mathrm{MHz}$ do $3 \mathrm{GHz}$ tehnički moguće i taktički opravdano da se funkcije COMINT i ELINT stanica integrišu u jedinstvenu radio-goniometarsku stanicu tipa SIGINT koja omogućava otkrivanje - detekciju, procenu smera detektovanih signala (azimuta i elevacije) $u$ 3-D prostoru, procenu parametara detektovanih signala, praćenje izvora signala po smeru, kao i prepoznavanje i identifikaciju svih izvora elektromagnetskog zračenja (komunikacionih, radarskih, navigacionih, IFF). U takvoj radio-goniometarskoj stanici tipa SIGINT bile bi integrisane i klasične funkcije COMINT stanica (analiza, prepoznavanje, prijem i praćenje komunikacionih signala). Integracijom funkcija COMINT-a i ELINT-a $\mathrm{u}$ istoj stanici, kroz fuziju podataka do kojih se dolazi kroz COMINT i ELINT funkcije, omogućava se pouzdanije otkrivanje i identifikacija letelica u vazdušnom prostoru.

Generički model radio-goniometarske stanice za nadzor vazdušnog prostora na pasivnom principu na bazi metode MUSIC

Osnovni zahtev koji se postavlja pred radio-goniometarsku stanicu tipa SIGINT za pasivan nadzor vazdušnog prostora, je da verovatnoća presretanja signala u zadatom frekvencijskom opse- 
gu i zadatom 3-D prostornom sektoru (klasični uskopojasni, radarski, signali sa frekvencijskim skakanjem) bude što bliža jedinici. Da bi se to obezbedilo, potrebno je da radio-goniometarske stanice za nadzor vazdušnog prostora budu tipa širokopojasnih intercept/DF stanica koje vrše prostorno-vremensko-frekvencijsku analizu signala $\mathrm{u}$ zadatom 3 -D prostornom sektoru i zadatom frekvencijskom opsegu. Presretanje signala sa frekvencijskim skakanjem predstavlja vršni zahtev u pogledu performansi ove stanice.

Problem nadzora vazdušnog prostora na pasivnom radio-goniometarskom principu može se, u tehničkom smislu, formulisati kao problem prostorno-vremensko-frekvencijske analize superponiranih signala koji potiču od aktivnih emitera elektromagnetskog zračenja u zadatom frekvencijskom opsegu i zadatom 3-D prostornom sektoru. Kroz dosadašnja istraživanja formulisan je i praktično verifikovan generalizovani prostorno-vremensko-frekvencijski model superpozicije radio-signala $\mathrm{u}$ zadatom prostornom sektoru, frekvencijskom opsegu i vremenskom intervalu. Modelom su takođe obuhvaćene i tehnike prenosa u proširenom spektru (spread spectrum tehnike frekvencijsko skakanje i direktna sekvenca). Predloženi matematički model je primenjiv za modeliranje svih tipova COMINT i ELINT signala koji se emituju sa vazduhoplovnih platformi. Navedeni model bio je osnovica za razradu tehničkih rešenja radio-goniometra za VVF/UVF opseg i praktično je verifikovan kroz ispitivanja prototipa ovog goniometra.

Iz takvog matematičkog modela proističe koncepcija generičkog modela radio-goniometarske stanice tipa SIGINT za nadzor vazdušnog prostora, koja je prikazana na slici 1. Model stanice sastoji se od antenskog niza, višekanalnog prijemnog sistema i signal procesorske platforme na kojoj se softverski implementiraju algoritmi za detekciju, procenu smera i procenu parametara primljenih signala. Procena parametara generalizovanog modela vrši se na bazi metode MUSIC (MUltiple SIgnal Clasification).

Kroz dosadašnje istraživačko-razvojne projekte u VTI, a posebno kroz razvoj radio-goniometra RGK-2/3, stečena su bogata teorijska i praktična iskustva vezana za metodu MUSIC. Tehničko rešenje za procenu smera u goniometru RGK-2/3 zasniva se na primeni ove metode. U sklopu vlastitih istraživanja autora razvijeno je više originalnih algoritama MUSIC tipa koji omogućavaju procenu parametara multikorisničkih spread spectrum signala sa direktnom sekvencom i frekvencijskim skakanjem. MUSIC je visokorezoluciona metoda koja je izvorno formulisana $u$ prostornom domenu kao metoda za procenu smera dolaska superponiranih signala. Omogućava procenu smerova dolaska više superponiranih signala koji se preklapaju vremenski i spektralno, što klasične metode za goniometrisanje ne omogućavaju. To praktično znači da je proces procene smera otporan na ometanje sve dok ukupan broj superponiranih signala koji se preklapaju vremenski i spektralno ne postane jednak broju antena $u$ antenskom nizu. U ovom radu dati su neki primeri koji ilustruju karakteristike metode MUSIC. Na slici 2 dat je 3-D prikaz a na slici 3 konturni prikaz procene azimuta $\mathrm{i}$ elevacije dolaska signala primenom metode MUSIC dobijen simulacijom. 


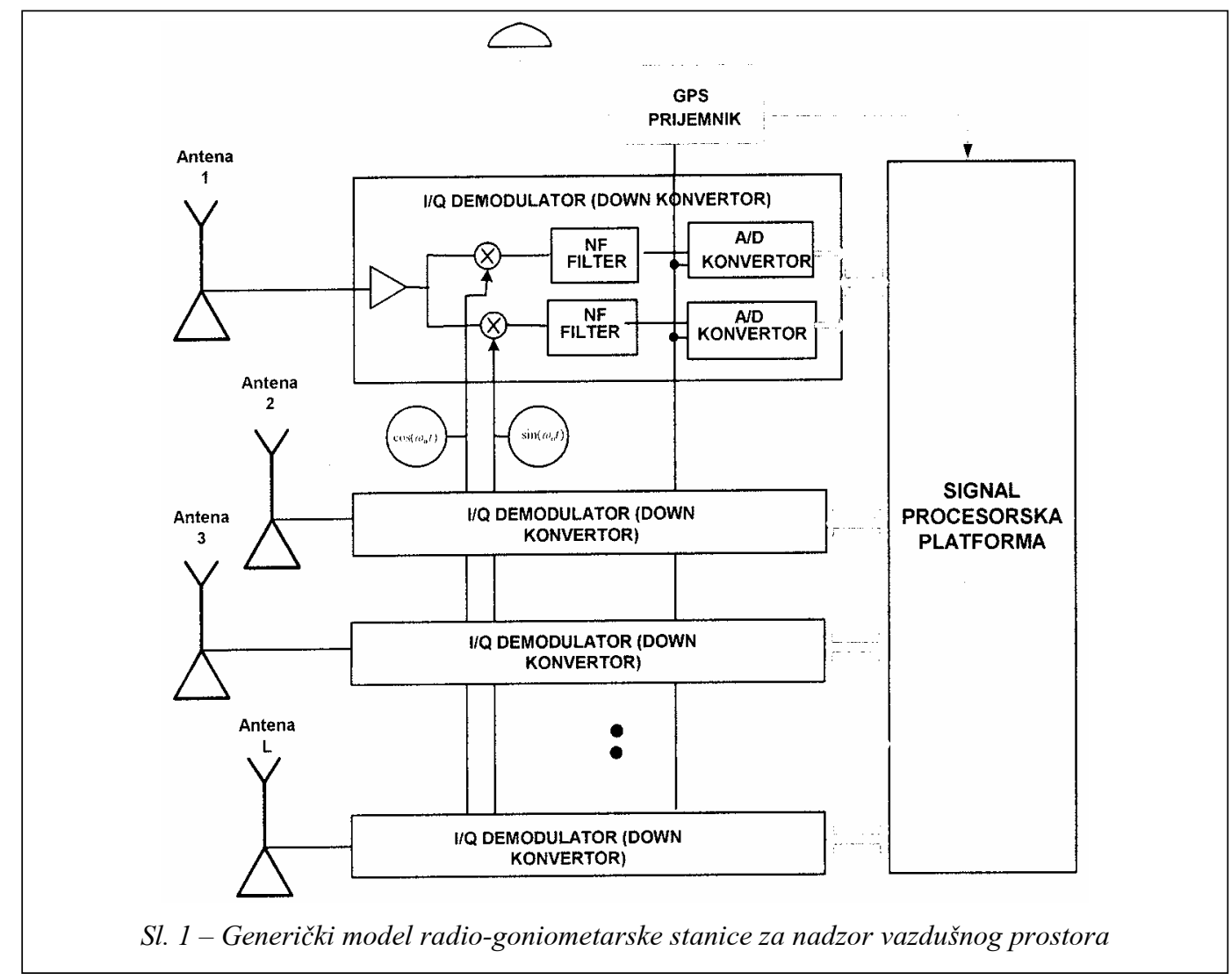

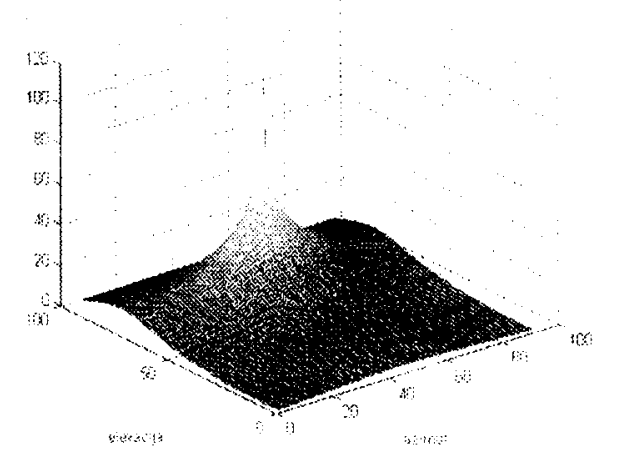

Sl. 2 - Procena azimuta i elevacije metodom MUSIC

Na slici 4 prikazani su rezultati prostorno-frekvencijske analize superponiranih radio-signala dobijenih primenom metode MUSIC. U zadatom frekvencij-

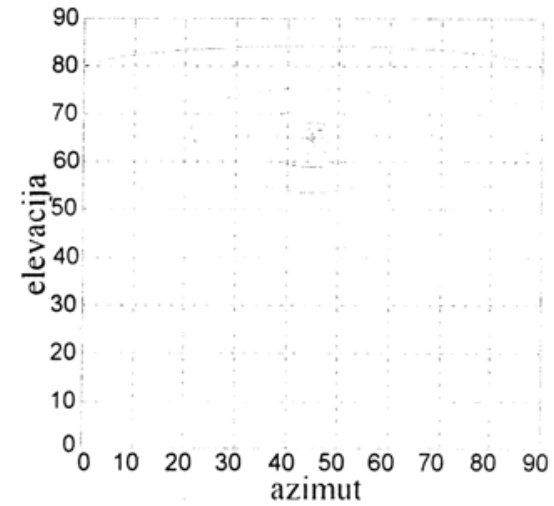

Sl. 3 - Kontura procene azimuta i elevacije metodom MUSIC

skom opsegu širine $6,4 \mathrm{MHz}$ aktivna su dva signala sa frekvencijskim skakanjem, jedan širokopojasni signal koji simulira ometajući signal baražnog tipa i jedan 


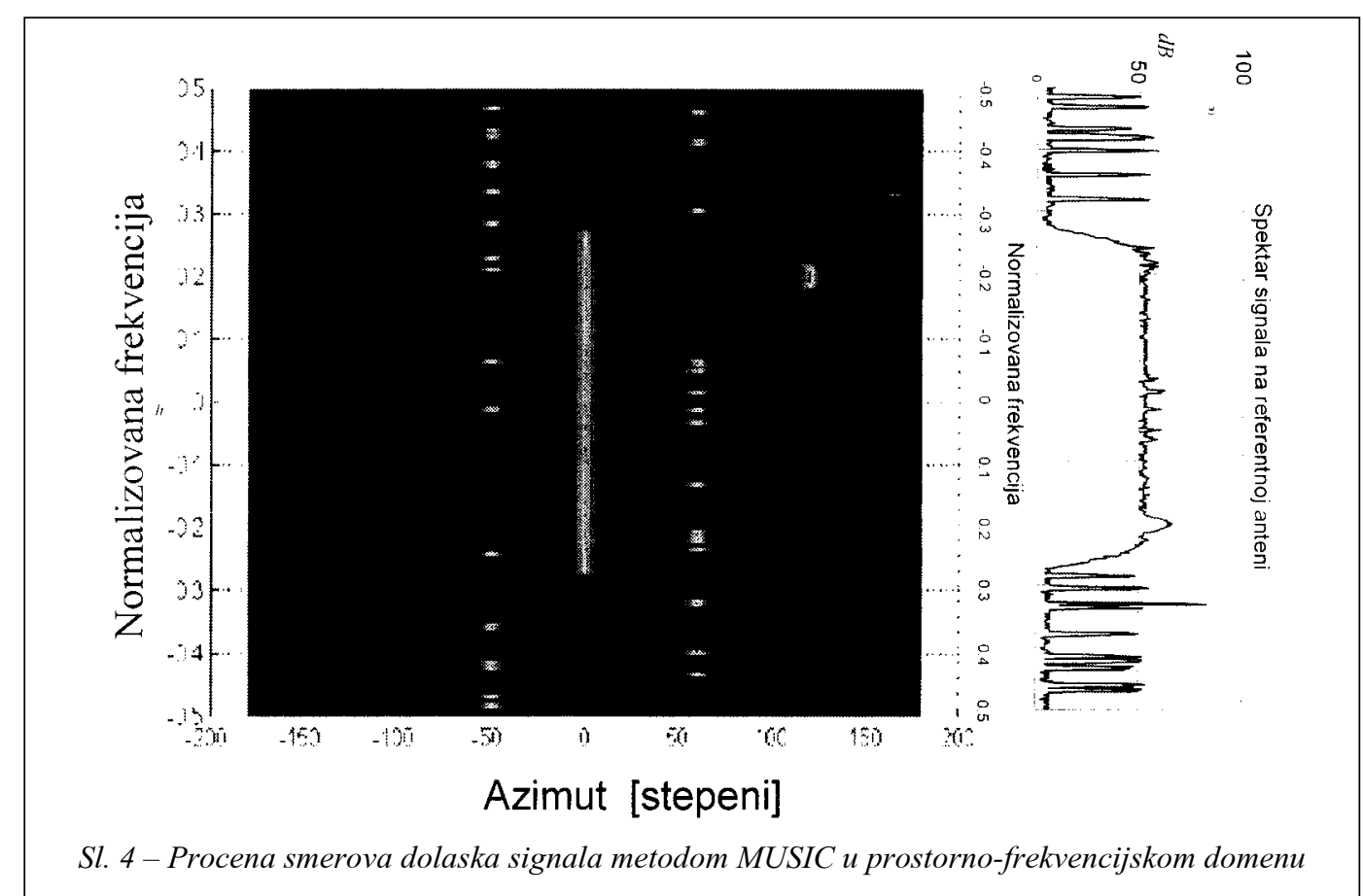

harmonijski nosilac. Sa slike se vidi da se na bazi prostorno-frekvencijske analize primenom metode MUSIC svi izbori mogu detektovati u prostorno-frekvencijskoj ravni u uslovima kada se signali preklapaju vremenski i spektralno. Na osno$\mathrm{vu}$ diskretnih tragova $\mathrm{u}$ prostorno-frekvencijskom domenu jasno se mogu identifikovati signali sa frekvencijskim skakanjem. Po kriterijumu smera dolaska vrši se razvrstavanje hopova različitih hopera što nije moguće uraditi u vremensko-frekvencijskom domenu, odnosno primenom klasičnih goniometara.

Sistemski parametar od suštinskog značaja za primenu metode MUSIC u radio-goniometarskoj stanici za nadzor vazdušnog prostora vezan je za tačnost određivanja smera ovom metodom. Na slici 5 dat je uporedni prikaz teorijske (Cramer-Raove) granice za standardnu devijaciju greške procene azimuta i standard-

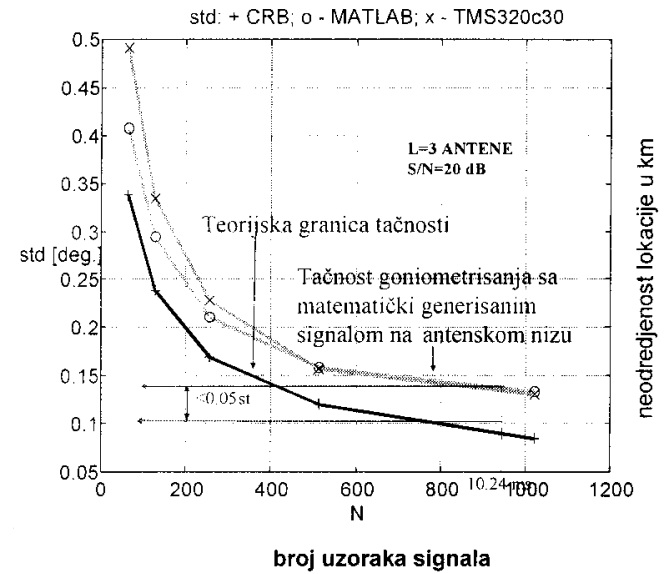

Sl. 5 - Uporedni prikaz teorijske Cramer-Raove granice za grešku procene $i$ greške procene pri implementaciji metode MUSIC u MATLAB-u i signal-procesoru TMS320c30

ne devijacije greške procene smera metodom MUSIC implementirane u MATLAB-u i na signal procesoru TMS$320 \mathrm{c} 30$ u prototipu radio-goniometra 
RGK-2/3. Vidi se da za slučaj tri antene, za odnos signal/šum od $20 \mathrm{~dB}$ i za 1024 uzorka signala $(10,24 \mathrm{~ms})$ teorijska granica tačnosti određivanja azimuta je ispod $0,1^{\circ}$. Implementacijom metode MUSIC na signal procesoru $\mathrm{u}$ istim uslovima, tačnost se degradira za oko $0,05^{\circ}$. Kroz praktičnu realizaciju metode MUSIC došlo se do saznanja da pri praktičnoj realizaciji metode MUSIC potencijalne performanse ove metode najviše degradiraju nesavršenosti prijemnog $\mathrm{i}$ antenskog sistema. Na slici 6 dat je prikaz neodređenosti lokacije emitera $u$ funkciji udaljenosti i greške određivanja smera. Pri teorijskoj Cramer-Raovoj granici greške određivanja smera, na udaljenosti od $120 \mathrm{~km}$, neodređenost lokacije je manja od 500 metara. Povećanjem broja antena $\mathrm{u}$ antenskom nizu, kao i povećanjem električnog otvora antenskog niza, može se postići zahtevana tačnost određivanja smera.

\section{Praktična iskustva u goniometrisanju vazduhoplovnih komunikacija goniometrom $R G K-2 / 3$}

U Vojnotehničkom institutu u periodu 1996-2000. godine obavljen je prototipski razvoj radio-goniometra za VVF/UVF, opseg 20-500 MHz, u okviru kojeg je izrađen i u realnim terenskim uslovima ispitan prototip radio-goniometra, koji je usvojen u NVO pod nazivom RGK-2/3. Na slici 7 prikazan je izgled prototipa radio-goniometra, [4]. Da bi mogao da se primeni za određivanje azimuta predajnika sa elevacijom postavljenom na vazduhoplovima, doradom softvera realizovana je mogućnost određivanja elevacije. Polazeći od navedenih is-

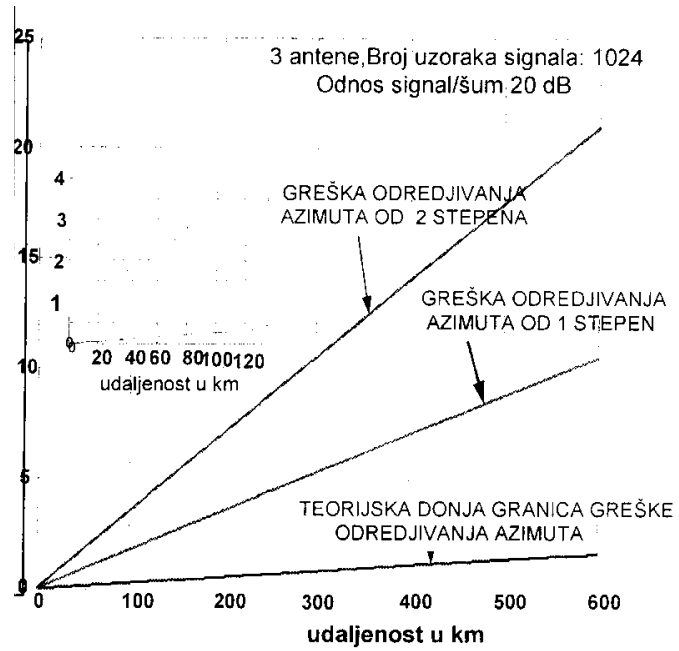

Sl. 6 - Neodređenost lokacije u funkciji udaljenosti i greške u proceni azimuta
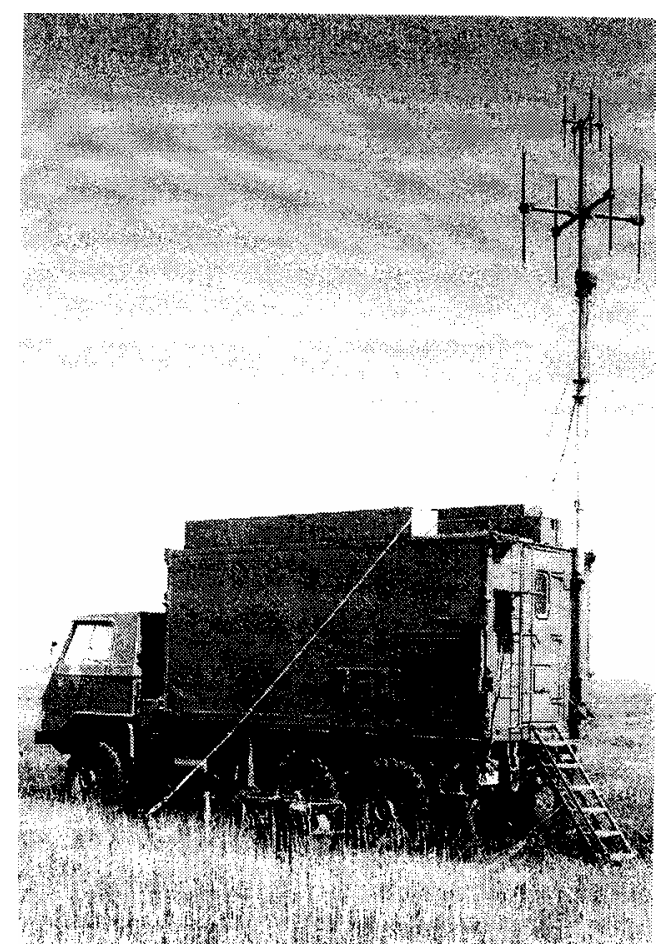

Sl. 7 - Prototip $R G K-2 / 3$

kustava radi kompletnog sagledavanja mogućnosti primene tehničkih rešenja radio-goniometra za nadzor vazdušnog 
prostora, izvršeno je ispitivanje tačnosti određivanja azimuta za predajnik sa elevacijom $\mathrm{i}$ ispitivanje daljine otkrivanja vazduhoplova goniometrisanjem predajnika na vazduhoplovu.

Na slici 8 prikazan je snimak procene azimuta i elevacije koji je dobijen goniometrisanjem radio-predajnika na helikopteru, pri čemu su stvarni azimut i elevacija helikoptera određivani na bazi podataka o poziciji helikoptera dobijenih od GPS prijemnika.

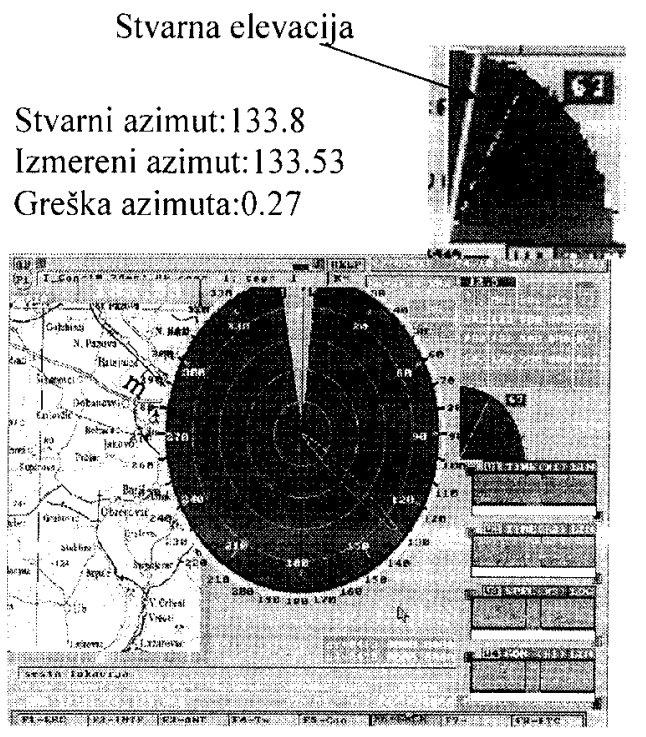

Sl. 8 - Snimak procene azimuta predajnika sa elevacijom postavljenog na helikopteru

\section{Predlog strukture podsistema za nadzor vazdušnog prostora na} radio-goniometarskom principu

Podsistem za nadzor vazdušnog prostora na radio-goniometarskom principu sastoji se od više stanica koje se prostorno dislociraju i koje su komunikacionim linkovima uvezane u jedinstvenu goniometarsku mrežu. Stanice se realizuju tako da svaka od njih može da bude upravljačka u goniometarskoj mreži. Određivanje lokacije u 3-D prostoru bi se vršilo na dva principa i to: triangulacijom smerova dolaska signala i presecanjem hiperpovršina koje povezuju skup tačaka u 3-D prostoru sa istim relativnim vremenskim kašnjenjem signala između parova stanica. U prvom slučaju, za što tačniju procenu lokacije potrebna je što tačnija procena smera dolaska signala na svakoj od stanica. U drugom slučaju potrebna je veoma precizna vremenska sinhronizacija stanica.

U oba slučaja potrebno je precizno određivanje vlastitih lokacija stanica, kao i prostorni razmeštaj stanica kojim se obezbeđuje optimalna goniometarska osnovica za triangulaciju. $U$ istim uslovima, princip lociranja na bazi merenja relativnog vremenskog kašnjenja ima bolje potencijalne performanse, ne zahteva posebnu kalibraciju višekanalnog prijemnog sistema, ali je osetljiviji s obzirom na istokanalnu interferenciju i zahteva moćnije komunikacione linkove.

Da bi se smanjio informacioni protok između stanica, na nivou svake stanice se vrši filtriranje podataka o procenjenim parametrima signala po nekom od definisanih kriterijuma kao što su frekvencija, prostorni sektor, parametri modulacije, impulsna frekvencija i sl.

Sistem za nadzor vazdušnog prostora na pasivnom principu bi se sastojao od podsistema strategijske i više podsistema operativno-taktičke namene koji bi bili uvezani u jedinstvenu mrežu. Stanice podsistema strategijske namene bi se razmeštale na pogodne lokacije za polustacionarni ili stacionarni rad. Ovaj podsistem bi omogućio nadzor vazdušnog prostora na strategijskoj dubini. Predlog 
strukture podsistema strategijske namene prikazan je na slici 9 .

Podsistem operativno-taktičke namene bi omogućio nadzor vazdušnog prostora iznad vlastite teritorije tipično $100 \times 100 \mathrm{~km}$. Ovaj podsistem bio bi prevashodno optimizovan za što preciznije određivanje lokacije i praćenje trajektorije letelica. Stanice ovog podsistema obavljale bi funkciju u stacionarnim, polustacionarnim i mobilnim uslovima.

Komunikacije između elemenata sistema predstavljaju izuzetno delikatan segment sistema, zbog toga što svojim radom mogu da demaskiraju rad sistema koji je pasivan. U tom smislu, povezivanje stanica u okviru strategijskog podsistema najbolje je izvesti na bazi optičkog kabla, koji pored zaštite od izviđanja i ometanja omogućava i velike brzine prenosa koje su neophodne za povezivanje ovih stanica. Stanice u podsistemu operativno-taktičke namene, zbog zahteva za mobilnost, povezuju se u bežičnu radiomrežu koja se zasniva na korišćenju neke od tehnika radio-prenosa koja je otporna na izviđanje i ometanje.

\section{Sprega podsistema za nadzor vazdušnog prostora na radio-goniometarskom principu sa podsistemom za radio-tehničko izvidanje}

Podsistem za nadzor vazdušnog prostora na radio-goniometarskom principu treba da bude funkcionalno integrisan i jedinstven sa sistemom za radio-tehničko izviđanje, $i$ to na nivou stanica i na nivou sistema. Fuzijom informacija koje se dobijaju na radio-goniometarskim stanicama i stanicama za radio-tehničko izviđanje, omogućava se stvaranje potpune elektromagnetske slike vazduhoplova na pasivnom principu i omogućava se njegovo pouzdanije otkrivanje i identifikacija.

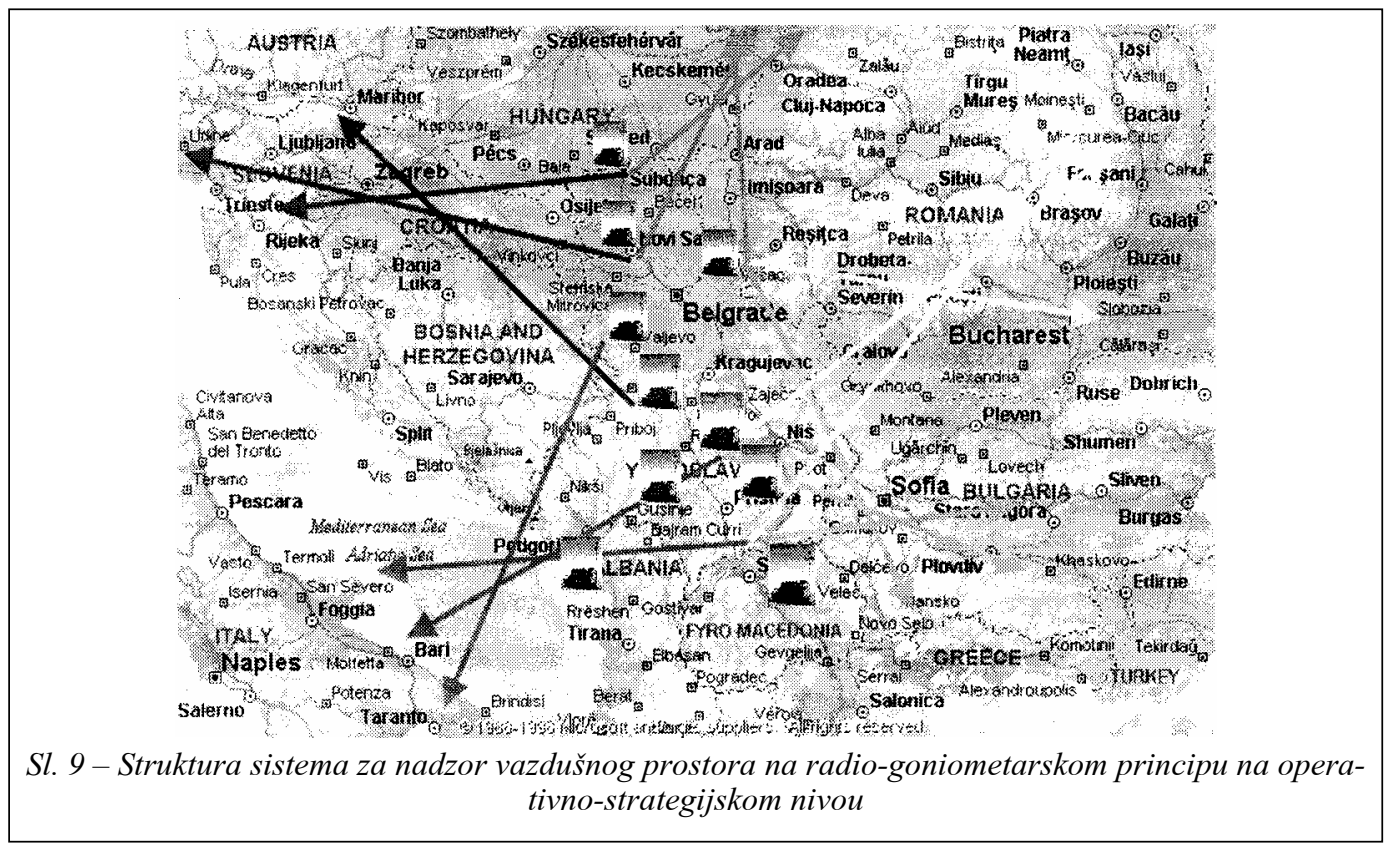




\section{Podsistem za nadzor vazdušnog prostora na zvukometrijskom principu}

Podsistem za nadzor vazdušnog prostora na zvukometrijskom principu predstavlja jedan od perspektivnih elemenata integrisanog multisenzorskog sistema za pasivan nadzor vazdušnog prostora. Ovaj princip je posebno interesantan zbog činjenice da vazduhoplovi u toku leta emituju akustičke signale koji se teško mogu sakriti ili maskirati. Do sada kod nas nisu vršena istraživanja u ovoj oblasti, ali je, na osnovu dostupne literature poznato da se u svetu rade intenzivna istraživanja. Prema raspoloživim informacijama $u$ Army Research Laboratory - SAD (tehnički institut oružanih snaga SAD) postoji istraživački projekat iz ove oblasti. Takođe, vrše se usavršavanja sistema „HALO" (sistem je razvijen u Engleskoj u „Roke Manor Research“ kompaniji za potrebe lociranja artiljerijskih oruđa na zvukometrijskom principu) koja treba da omoguće primenu ovog sistema za otkrivanje i lociranje helikoptera i radarski nevidljivih vazduhoplova na zvukometrijskom principu.

$\mathrm{Na}$ osnovu do sada obavljenih analiza snimljenih akustičkih signala, može se zaključiti da vazduhoplovi u toku leta generišu akustički signal $u$ infrazvučnom $i$ čujnom delu spektra. Iz literature je poznato da infrazvuk ima daleko manje slabljenje pri propagaciji od čujnog dela spektra, i da se na bazi infrazvuka može vršiti detekcija vazduhoplova na udaljenostima od par stotina kilometara.

Međutim, procenjuje se da je prava perspektiva primene zvukometrije $\mathrm{u}$ pasivnom nadzoru vazdušnog prostora ve- zana za pokrivanje teritorije koja se nalazi u radarskim maskama aktivnih radarskih sistema, pri čemu se pod pokrivanjem podrazumevaju procesi detekcije otkrivanja, određivanja koordinata, praćenje trajektorije i automatska identifikacija vazduhoplova koji lete podzvučnom brzinom i na visinama do 300 metara (helikopteri, niskoleteći avioni, bespilotne letelice, krstareće rakete, radarski „nevidljivi“ avioni sa primenjenom ,stealth“ tehnologijom za smanjenje radarskog odraza, itd.).

\section{Koncepcija podsistema za nadzor vazdušnog prostora na zvukometrijskom principu}

$\mathrm{Na}$ osnovu dosadašnjih iskustava i raspoloživih saznanja, nameće se zaključak da podsistem za nadzor vazdušnog prostora na zvukometrijskom principu treba da bude koncipiran kao distribuirani sistem ćelijskog (celularnog) tipa, koji se sastoji od više identičnih zvukometrijskih stanica StZI VOJ koje su međusobno povezane komunikacionim linkovima. Stanice se postavljaju tako da formiraju ćelijsku strukturu tipa paukove mreže kojom se pokriva određeni prostorni sektor. Međusobni razmak stanica je takav da akustički signal koji se generiše pri letu vazduhoplova mogu da istovremeno detektuju najmanje 3 do 4 susedne stanice $u$ sistemu tokom čitave trajektorije leta vazduhoplova unutar zadatog prostornog sektora. Da bi ovaj podsistem to omogućio, on treba da ima osobine samoorganizujućeg rekonfigurabilnog sistema, da ima mogućnost obrade signala na svakoj od stanica i mogućnost međusobne razmene podataka posredstvom komunika- 


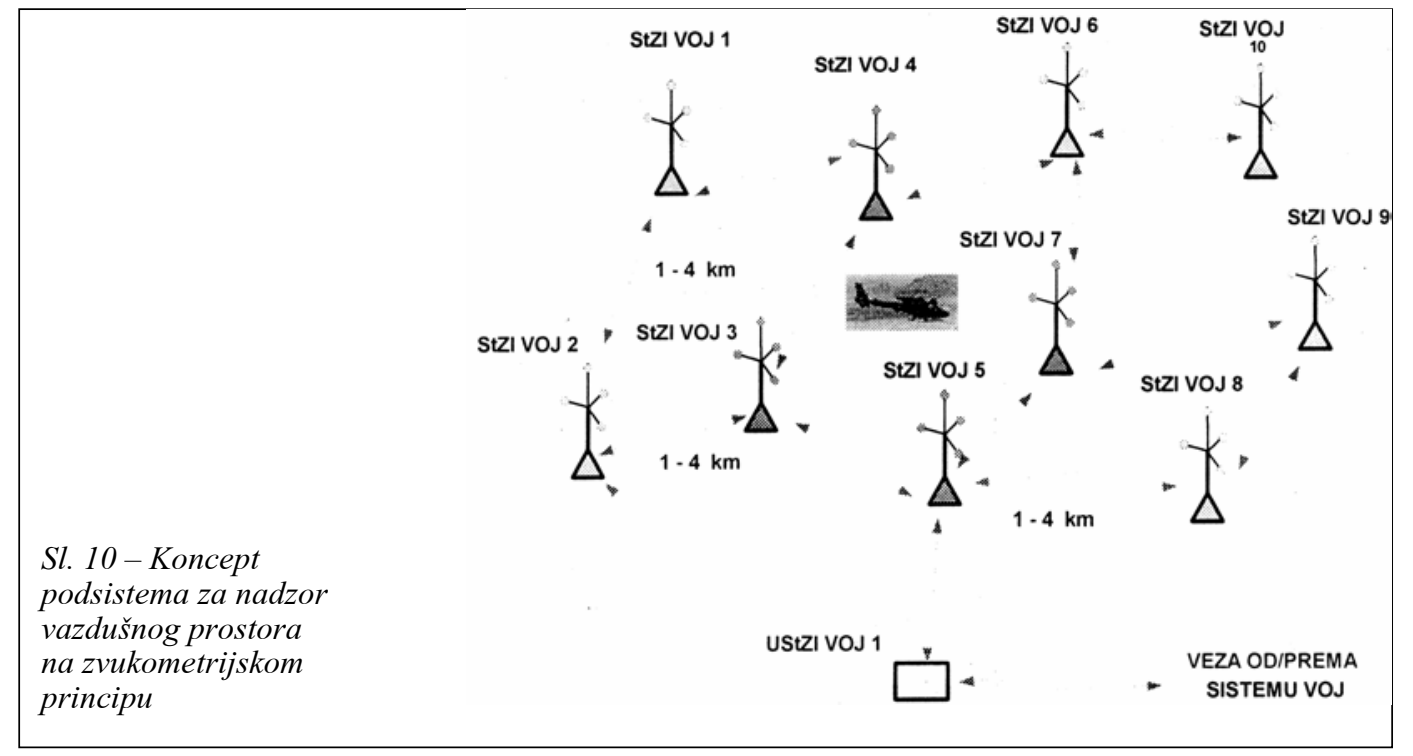

cionih linkova. Na osnovu raspoloživih znanja i informacija iz informaciono-komunikacionih tehnologija procenjuje se da ovaj podsistem treba da bude koncipiran i implementiran kao distribuirani ADHOC senzorski sistem. Idejno rešenje koncepcije podsistema, koje će biti predmet daljih istraživanja, prikazano je na slici 10. Procenjuje se, takođe, da ovaj podsistem može da bude veoma efikasan za zaštitu državne granice kako u dnevnim tako i u noćnim uslovima.

\section{Zaključak}

Predloženi koncept podsistema za nadzor vazdušnog prostora na radio-goniometarskom principu u frekvencijskom opsegu 20-3000 MHz, i podsistema na zvukometrijskom principu, koji je u ovom radu prikazan u osnovnim crtama, u potpunosti se mogu realizovati u našim uslovima na bazi dostupnih tehnologija i vlastitih znanja. Kroz dosadašnje istraživačke i razvojne projekte u oblasti sistema za elektronski rat u VTI, a pogotovu kroz razvoj radio-goniometra $\mathrm{RGK}-2 / 3$, stečena su dragocena i upotrebljiva znanja i iskustva koja to potvrđuju.

Literatura:

[1] Schmidt R.: Multiple emitter location and signal parameter estimation, IEEE Trans. on Ant. and Prop., Vol. AP-34, No. 3., March 1986.

[2] Erić, M.: Prostorno-frekvencijska analiza radio-frekvencijskog spektra, doktorska disertacija, Fakultet tehničkih nauka, Novi Sad, 1999.

[3] Erić, M.; Lipovac, L.; Gordić, R.; Lazović, M.; Kostić, A.; Jolkić, S.: Koncept distribuiranog sistema za nadzor vazdušnog prostora na pasivnom principu, XI telekomunikacioni forum Telfor 2003, Beograd, Sava centar, 25-27. 11. 2003.

[4] Monografija „,50 godina Vojnotehničkog instituta“, Beograd, 1998, str. 83 . 